Przegląd Badań Edukacyjnych Educational Studies Review

ISSN 1895-4308

nr 35 (2/2021), s. 213-234

METAANALIZY

BADAŃ

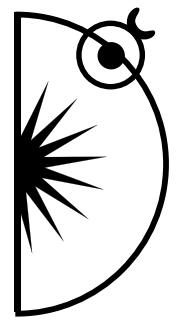

Zdzisława Janiszewska-Nieścioruk

University of Zielona Gora, Poland

e-mail: z.janiszewska-niescioruk@wns.uz.zgora.pl

ORCID: https://orcid.org/0000-0003-2874-1524

\title{
Social and Educational Context of the Poverty of People with Disabilities in Poland
}

http://dx.doi.org/10.12775/PBE.2021.040

\begin{abstract}
:
The article points out the high complexity and multidimensionality of the hot social issue of poverty as well as the related unemployment, and the precariousness of people with disabilities in Poland. The author notes that despite the currently promoted pro-inclusion activities and solutions for their benefit in connection with the implementation the assumptions of the Convention on the Rights of Persons with Disabilities in Poland, with insufficient support, these problems may multiply and aggravate the disability and special needs of these people. People with disabilities still too often live in conditions of poverty that have a negative impact on their development and functioning in all spheres or areas of social life, as well as in the open labour market. In the process of compensating for the shortcomings related to having been brought up in a poor family, education has a significant role to play. Therefore, the author stresses its significant importance for the process of equalizing educational opportunities for children, as well as for the weaknesses noticed in its space, which hinder this process. The author pays equal attention to the threat of these people with unemployment and precariousness, which often destabilize their lives and hinder inclusion in the local and wider community.
\end{abstract}

Keywords: poverty, precariousness, unemployment, people with disabilities, social and educational context of poverty. 


\section{Introduction}

The multidimensional and dynamic process of contemporary globalization creates a lot of new opportunities for all people, including those with disabilities and special needs, at the same time posing a lot of challenges that the latter are often unable to meet. Finding oneself and functioning in the new conditions of a globally and civilizationally changing world without the practical tools i.e. key competences $^{1}$ and personalized support (Schalock et al., 2010; Sęk \& Cieślak, 2011) may result in poverty pushing such people to the margin of social life. Marginalization, social exclusion and poverty are closely related, and disability, like other social problems, e.g. unemployment or precariousness, is very likely to occur (Szarfenberg, 2006; 2016; Golinowska, 2008; 2010; Standing, 2014; Becker-Pestka et al., 2017). It can be assumed that the presence of disability multiplies this risk. This is confirmed by the data of the European Commission which showed that as many as $30.1 \%$ of such people $(20.9 \%$ in the case of non-disabled people) were at risk of poverty or social exclusion, including $36.1 \%$ of people with a serious/severe disability (aged 16 or over), the figures were lower for people with a moderate degree of disability reaching $27.4 \%{ }^{2}$. It should be stressed that in Poland poverty affects particular groups of people to a varying degree, but the social map of the risk of this problem in our country has not changed significantly for many years. There is a noticeable improvement related to a slight reduction in the extent of extreme poverty (in $2018-8.0 \%$, and in $2019-3.5 \%$ ) in situations where people with a certificate of disability are members of the household, but no significant change was noted in the case of farms with at least one child under 16 with such a certificate (in $2018-5.7 \%$, and in $2019-5.5 \%)^{3}$. As it can be assumed, the situation of many families with children with disabilities in the context of the changes in the labour market currently experienced by Polish society, caused by the announcement of the

${ }^{1}$ Official Journal of the European Union, Council Recommendation of May 22 nd, 2018 on Key Competences for Lifelong Learning. Retrieved 30 July 2020 from: https://eurlex.europa.eu/ legalcontent/PL/TXT/PDF/?uri=CELEX:32018H0604 ( 01) \& from = EN.

2 European Commission, Brussels, Draft Joint Commission-Employment Report accompanying the Communication from the Commission on the Annual Growth Survey 2019. Retrieved 30 July 2020 from: https://ec.europa.eu/info/sites/info/files/file_import/2019-european-semestercountry-report-poland.pl.pdf.

${ }^{3}$ GUS, The scope of economic poverty in Poland in 2019. Retrieved 31 July 2020 from: https://stat.gov.pl/obszary-tematyczne/warunki-zycia/ubiasto-pomoc-spoleczna/zasieg-ubstwaekonomicznych-w-polsce-w-2019- year, 14.7.html? pdf $=1$. 
state of SARS-CoV-2 epidemic from March 20, 20204, could have deteriorated significantly. One of the possible reasons is the job loss and a sudden reduction or lack of income in families burdened with additional costs of rehabilitation of a disabled person, which contributes to their poverty, social marginalization and exclusion. Another equally important issue is the actual availability and quality of medical, rehabilitation and support services in this particular period.

Poverty of people with disabilities, analysed in the context of the phenomenon of marginalization and exclusion, is associated with a situation of deprivation, deprivation of needs in absolute or relative terms, but also, often with the withdrawal of these people and their families from participation in the social space, i.e. auto-marginalization and self-stigmatisation (Radziewicz-Winnicki \& Roter, 2004; Goffman, 2005; Nyes, 2012b). When the category of poverty is extended, it is not limited to financial resources only, but takes into account other spheres of life as well, e.g. housing, education, work or health, then this concept is close to the concept of social exclusion. It is not synonymous with it, but it can be one of the factors that often coexists, especially in relation to people with disabilities (Mikołajczyk-Lerman, 2013).

Poverty, being an undesirable phenomenon due to its scope, intensity or nature of its consequences, while being reflected and therefore critically assessed by at least a part of the society, is still a socially sensitive problem (Horton \& Leslie, 1970, after: Kaźmierczak-Kałużna, 2012). Especially that the process of socialization of children in poverty often determines their resources and predispositions to their multiplication, i.e. the habitus (Roter, 2005; Bourdieu \& Passeron, 2006; Karwacki, 2006; Jarosz \& Kozak, 2015). Therefore, it may be of significant importance for their development, education and rehabilitation, especially when negative school-related experiences are intensified by practices that socially stratify students, launched in its space, de facto replicating their statuses (Smolińska-Theiss, 2008; 2016; Tarkowska, 2008; 2013; MikołajczykLerman, 2013; Melosik, 2015).

Bearing in mind the above considerations, as well as the cited research results, it is necessary to emphasize the high complexity or multidimensionality of the problem of poverty and the related unemployment and precarization

${ }^{4}$ Journal of Laws 2020.491, Version from: March 31, 2020 Regulation of the Minister of Health of 20 March 2020 on the declaration of an epidemic in the territory of the Republic of Poland. Pursuant to art. 46 par. 2 and 4 of the Act of 5 December 2008 on preventing and combating infections and infectious diseases in humans (Journal of Laws of 2019, items 1239 and 1495 and of 2020). Retrieved 31 July 2020 from: https://sip.lex.pl/akty-prawne/dzu-dziennik-ustaw/ ogloszenie-na-obszarze-rzeczypospolitej-polskiej-stanu-epidemii-18972567. 
of people with disabilities in Poland that often accompany them. With insufficient support, despite the currently popularized pro-inclusion activities and solutions for their benefit, the disability and special needs of these people may be multiplied and intensified by them or because of them. Thus, despite the right to an inclusive education and rehabilitation system at all levels, and the right to work in an open, inclusive and accessible environment (with reasonable improvements), full participation in society is necessary, as I emphasize in this article, drawing attention to the fact that people with disabilities still too often live in conditions of poverty that have a negative impact on their development and social relations (cf. Convention on the Rights of Persons with Disabilities, 2006). Therefore, in the process of levelling the gaps in this area, which I shall also point out, education, and pre-school education in particular, has an important role to play. It is kindergarten and the first years of primary school education that may be decisive in the process of equalizing educational opportunities and social inclusion of children, and the weaknesses noticed in its space hinder this process. I shall pay equal attention to the problems of unemployment and precariousness as highly negative phenomena related to poverty and therefore severely experienced by this group of people and their families. I shall therefore analyse the proposed issues in two contexts / aspects - educational and social, closely related to each other in terms of conditions, course and consequences for the currently disseminated social and educational inclusion of children, adolescents and adults with disabilities.

\section{The first problem}

\section{Educational context of poverty - the key role of education, especially pre-school education, in the process of compensating for the deficiencies in the field of socio-cultural capital of people with disabilities}

One of the most important and characteristic features of current poverty in Poland, without downplaying its negative effects on other social groups, is the poverty of children and adolescents, families with many children ${ }^{5}$, as well as a very difficult situation related to unemployment or finding employment in the open labour market by young adults. I shall present the issues of employ-

\footnotetext{
${ }^{5}$ The extent of extreme poverty in 2019 in households with children aged 0-17 in the case of families with 2 and 3 children was as much as $11.9 \%$, GUS, Range of economic poverty in Poland in 2019.
} 
ment (especially unemployment and precariousness) in the next thread, including this issue as a consequence of the poverty experienced by children in the family and the generally accessible school's failure to cope with this problem. Meanwhile, the role of educational and care institutions (closely cooperating with each other) is undoubtedly a priority, both in preventing child poverty and mitigating its effects, as "however cruel it sounds, some are simply born in poverty. They grow in a sense of powerlessness and helplessness, and poverty is their first and natural experience. This is often the only legacy. Escaping it requires extraordinary wisdom, luck and hard work. It is especially difficult when the bad economic situation is associated with a chronic disease

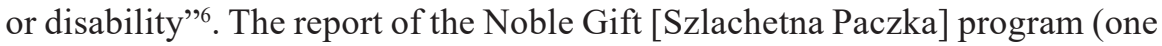
of the most recognizable and well-organized social projects in Poland, based on the work with donors and volunteers supporting poor families, in operation since 2001) states that as many as $45 \%$ of large families have at least one person with a disability and in one in four $(26 \%)$ there is a disabled child or children.

Izabela Kaźmierczak-Kałużna (2016; 2019a) draws attention to these phenomena, i.e. numerousness and poverty, which can be mutually correlated. The author, when making a list of various areas of childhood of mothers with many children and their children's childhood (including those with disabilities), found that the narratives of the respondents most often included statements depicting poor and busy childhood, dominated by permanent scarcity. An important feature of these statements was also the topic of child labour - excessive housework, the need to engage in paid work to contribute to the home budget, field work (sometimes at the expense of school duties) and the burden of care and responsibility for others, especially younger siblings. Unfortunately, the situation of children of the surveyed mothers is similar. Financial shortages and little interest of mothers in children's educational careers limit their chances of changing their life situation. Children did not take advantage of the diverse offer of additional activities organized by schools or other forms of activities involving them in the children's and local community (Kaźmierczak-Kałużna, 2016). Thus, the barriers to education that children and young people from families affected by poverty and unemployment continue to face are many and varied. These are not only financial difficulties, e.g. lack of funds to purchase text-

${ }^{6}$ Szlachetna Paczka, Report on Poverty, 2018. Retrieved 8 April 2020 from: https://www. szlachetnapaczka.pl/wpcontent/uploads/2019/10/szlachetna-paczka-raport-o-biedzie-2018-1.pdf, p. 8. 
books and necessary school supplies, pay for additional classes or joint trips, the need to earn money, housing difficulties and the related lack of own place to work, but also the lack of support from parents who do not have sufficient competences and are focused on meeting the basic needs of the family. Unfortunately, these also include social and cultural barriers, e.g. underestimating education, environmental patterns of a career path, which leave no room for learning. Psychological barriers are also burdensome, e.g. low self-esteem, lack of self-confidence, and - in the case of children living far away from school such a barrier will be tiring and time-consuming commuting de facto excluding them from participation in extra-curricular activities (Tarkowska, 2006; Nowak, 2012a, 2012c).

Therefore, systemic solutions are necessary in the process of educating children/students with disabilities within the environment of poverty and social marginalization, from families with a low socio-economic status and cultural capital, which would take into account their specific situation already in the pre-school period. It is the kindergarten and the first years of primary school education that may be decisive in the process of equalizing educational opportunities and social inclusion of these children. Meanwhile, on their way to education, they still experience many barriers, not only economic, social and cultural, but also no less severe - psychological. Moreover, as Elżbieta Tarkowska et al. aptly noted over a decade ago, as well as Kaźmierczak-Kałużna (2016, 2019a) showed in her research, "education is not facilitated by the phenomenon of 'the lack of childhood' or 'the shortened childhood', which is so typical of poverty, as a result of early gainful work for the family, and sometimes also - premature taking responsibility for it" (Tarkowska et al., 2006, p. 30). We still know too little about the current problems in the school of these students, how their colleagues respond to them, and how teachers and other specialists involved in the process of including them react to them, what support they may expect, and what its actual availability and quality are.

The Family 500+ program implemented in 2016-2018 had a certain impact on the reduction of poverty in Poland (financial aid for families raising children in the form of a child care benefit in the amount of PLN500, currently for each child up to the age of 18), increased the level of financial security and satisfaction of the basic needs in the least affluent households (Mendryk et al., 2020). Without doubt this program has reduced the area of poverty, however, as noted by Małgorzata Gasz (2018), within a longer time perspective, the policy of attractive social benefits may adversely affect the structure of the labour market. It did not meet demographic expectations either as the number of births in Po- 
land has not risen significantly. Although the economic situation of many of the poorest families, especially those with many children, has improved, "it is difficult to predict what significance it will assume, noticeable from the Program's entry into force, professional deactivation of some women, and also to what extent the Program will develop demanding and clientelist attitudes towards the state in Polish families" (Kaźmierczak-Kałużna, 2019b; Krawczyk, 2019, pp. 61-62).

The issues of the lack or low quality of pre-school education and stratification practices launched within the school space in relation to children/students from poor families and of a low socioeconomic status have been dealt with in many publications so far (Kwieciński, 2002; Murawska, 2004; 2006; Tarkowska, 2006; 2008; Szkudlarek, 2007; Dolata, 2008; Melosik, 2015; Śliwerski, 2015). The indicated problems in connection with the disability or special needs of children may seriously hinder, and sometimes even prevent, the realization of educational opportunities. They are - in some way - a contradiction of postulates and actions aimed at equalization. Meanwhile, it is pre-school and early school education that play a key role in the process of supplementing gaps, lacks or deficits in terms of sociocultural capital, knowledge and skills derived from the family environment. Therefore, it is of great importance for children from the educational risk group, including those with disabilities or with special needs. Thus, its compensatory and therapeutic values should be appreciated by both decision-makers and politicians, regardless of their political pedigree (Janiszewska-Nieścioruk, 2012).

Pre-school education, especially early education, undertaken in Poland as early as at the age of 3, but also family and nursery education (up to the age of 3 ), should play an important role in the socialization policy of the state. There are, however, some omissions in this respect: there are limitations in access, as well as the unequal distribution of this access in the countryside and in the city/ town areas: $93.5 \%$ and $55.2 \%$ respectively in the 2018/2019 school year. The pre-school education dissemination rate in the 2018/2019 school year among children aged 3-5 in Poland amounted to $87.3 \%$ and, as it was added, it increased by $2.6 \%$ compared to the previous school year, but it differs among individual provinces. The lowest rates - less than $70 \%$ of children aged 3 (a total of $77.7 \%$ in 2018/2019 school year) were covered by pre-school education in the Warmian Masurian and the Kuyavian Pomeranian provinces, while the indicator of $80 \%$ was not achieved in as many as 10 provinces and only in 3 the $80 \%$ threshold was slightly exceeded; the highest rate $-85.5 \%$ was obtained in Masovian. Higher rates were established in the case of pre-school education for 
children aged 4 and 5, but also in this case $100 \%$ of children were not covered by this form of education ${ }^{7}$.

An equally important issue, as I have already indicated, is including children aged under 3 in early education programs in Poland. The number of children covered by this education grows slowly, depending on the socioeconomic conditions of the family and the level of parents' education. In 2010-2017, the enrolment rate of children under 3 in early childhood education programs increased from $9.9 \%$ to $11.6 \%$ (EU average: $34.2 \%)^{8}$. Despite measures taken to improve the availability of institutional pre-school care for children, serious problems were encountered in as many as 14 out of 30 communes audited by the Supreme Audit Office. As established, the number of applications for the admission of children exceeded the number of places available by an average of $30-60 \%$. Almost $1 / 3$ of children did not get into the selected kindergarten, and nearly all of them were three- and four-year-olds. At the same time, most parents were not fully satisfied with the equipment of the kindergartens, the scope of the care they provided, and the lack of possibility to attend them during holidays. What is equally important, a large group of parents (16\%) indicated that kindergartens did not provide adequate conditions for children with specific health needs, related mainly to allergies and chronic diseases ${ }^{9}$.

The situation depicted obliges us to take quick and effective actions to popularize and improve the quality of preschool education for children with disabilities and special needs, especially those from families with low socioeconomic and cultural status. Undoubtedly, it will not be an easy task to fulfil, especially in the current situation - material-, financial- and social-wise. Still, increasing institutional care for young children, already up to the age of 3 , is not only a condition for equalizing their educational opportunities, but as it becomes the basic tool of family policy, it can make it easier for their parents/ guardians to combine family and professional responsibilities. It may also contribute to the improvement of the situation of women on the labour market,

${ }^{7}$ Education and upbringing in the 2018/2019 school year, GUS, Statistical Office in Gdansk, Retrieved 8 April 2020 from: oswiata_i_wychowanie_w_roku_szkolnym_2018_2019_korekta_12-02-2020.pdf.

${ }^{8}$ Monitor Kształcenia i Szkolenia 2019, Poland. Retrieved 8 April 2020 from: https:// ec.europa.eu/education/sites/education/files/document-library-docs/et-monitor-report-2019-poland_pl.pdf.

9 Places in a kindergarten not for everyone, NIK on the provision of pre-school care by municipalities 2019. Retrieved 4 April 2020 from: https://www.nik.gov.pl/aktualnosci/miejsce-wprzedszkolu-nie-dla-wszystkich.html. 
increase in their employment and the expected fertility rate (Kotowska, 2007; Janiszewska-Nieścioruk, 2012). Good quality, early and financially accessible care and educational services - varied in their organizational, curricular and support scopes - can be an effective way to reduce inequalities between children. The mere kindergarten attendance of children aged of 3-4, as shown in the research more than a decade ago by Barbara Murawska $(2004 ; 2006)$, was one of the important criteria for their allocation to a specific school group/class. Children's participation in pre-school education was associated with a higher level of school skills, but also with the socioeconomic status of their families. The quality of education offered to children in a given pre-school and then school form largely depended on their socially significant characteristics, such as the place of residence, education and material status of their parents. Equally important was the involvement and willingness of parents to support their child in the educational process and, if necessary or advisable, in the often lengthy rehabilitation process. Thus, children who are not enrolled in pre-school education or are included in it too late, come from families with low socio-cultural capital and suffer from disabilities not getting an opportunity to fill the gaps early through stimulation, multi-specialist diagnosis and correction of possible deficits, flaws and other irregularities that hinder later learning and contacts with peers. The introduction of basic and systemic solutions in this respect, favouring the inclusion of children from poor families and those with low SES in the public school space will create real conditions for ending the severely experienced cultural, social and economic deprivation (Tarkowska et al., 2006; Tarkowska, 2008; Janiszewska-Nieścioruk, 2012). They will, at the same time, alleviate their social stratification, strengthen self-esteem and enable the creation of their own self.

Therefore, full availability of pre-school education (including nursery schools) is expected, regardless of the place of residence and parents' resources, counteracting the practices of social segregation in schools as a consequence of deficits or deficiencies in the family environment, and appreciating the native education system as a tool of the pro-development policy of the state and the region (Śliwerski, 2008; 2015). The existing, too often ad hoc measures and solutions in Polish education should be replaced with long-term approaches, and they should be considered primarily in terms of investments, not costs. It is also necessary to make kindergartens/schools independent and devoid of bureaucracy, as well as delegate the supervision to those who cooperate with each other, use these institutions and work in them - teachers and other specialists, pupils and their parents, as well as local entities with varying degrees of 
involvement in the process of their support and social inclusion. With such an approach, a kindergarten or school is not an isolated entity in the local environment, but includes pupils, and at the same time becomes an institution in the life of the local community - it opens up to the social environment and the social bonds existing in it (Senge, 2012).

\section{The second problem}

\section{The social context of poverty - people with disabilities as "loose" people; too often outside the labour market or in the precarious trap}

The "looseness" of people with disabilities signalled in the subtitle is to be understood metaphorically and associated primarily with the consequences of socioeconomic and civilizational transformations often severely experienced by them, especially with the irregularity of professional work, short duration of employment, unemployment and precariousness, as well as with a sense of temporariness, addiction to others, and even social marginalization (Poniat, 2013; Szarfenberg, 2016; Pałęcka \& Płucienniczak, 2017).

As shown by the latest results of the Labour Force Survey and Unemployment ${ }^{10}$ registered in the second quarter of 2020 (of August $25^{\text {th }}, 2020$ ), the changes in the labour market in Poland were significantly influenced by the situation related to the pandemic - restrictions in movement, the need to maintain social distance, as well as difficulties in the operation of many companies and branches of the economy. The data show that there was an increase in the number of unemployed and inactive people aged 15 and over, the indicator reached the value of $44.5 \%$. Unfortunately, as many as 58.8 thousand people with disabilities were registered as unemployed, and among the economically inactive at working age, people with disabilities and the ill also accounted for a significant group of $23.4 \%$. However, it should be emphasized that in the recent years, the disproportion between employees with disabilities registered in the Subsidy and Reimbursement Service System (SODiR) of the State Fund for Rehabilitation of Disabled Persons (PFRON) from the open and protected labour market has

${ }^{10}$ GUS, Information on the labour market in the second quarter of 2020. (preliminary data). Part I. Results of the Labour Force Survey and Registered Unemployment in Q2 2020. Retrieved 29 August 2020 from: https://stat.gov.pl/obszary-tematyczne/rynek-pracy/pracujacy-bezrobotnibierni-zawodowo-wg-bael/informacja-about-labor-market-in-the-second-quarter-2020-data-preliminary, 12,42.html. 
been clearly diminished. The share of employees from the open labour market in relation to the total number of employees with disabilities was higher than the share of employees from the protected market ${ }^{11}$. Taking into account the degree of disability, there is a noticeable greater problem with employing people with a mild disability, which indicates the difficulties of these people in finding a job on the open market. The data quoted indicate the still unfavourable situation of people with disabilities on the labour market, too often related to the lack of it or their inactivity. At the same time, among the registered unemployed, the largest group were people with a slight degree of disability, who, due to the smallest limitations in functioning, should find employment more often. One of the reasons for this may be the lack of subsidies for employers employing such workers, but also underestimating competences and negative attitudes towards these people. Meanwhile, this form of life activity makes it possible to meet the need of belonging and acceptance in the situation of performing joint work, inspires to take up new challenges and improve competences (lifelong learning). It is of great importance for creating one's own lifestyle, taking into account personalized forms of support only when it is necessary and expected (Brzezińska et al., 2008b).

Work, employment, and thus - expanding the area of independence and self-determination, is undoubtedly of particular importance to people with intellectual disabilities. By promoting the normalization of life and social inclusion, it inspires the process of their self-rehabilitation (Kosakowski, 2009; Krause et al., 2010; Żółkowska, 2004; 2011). Therefore, it is advisable to professionally activate people with varying degrees of disability already at the stage of education, and especially to make the process of their training or retraining in adulthood more flexible after completing formal education (Wolny, 2020). Therefore, it is important that the process of the transition of people with disabilities, including those with intellectual disabilities, from education to the labour market takes into account their individual needs, strengths and weaknesses and, which is equally important, their interest. Actions are needed to raise the level of school achievements and improve the adaptive functioning of those people, which increase the effectiveness of their employment and social inclusion (Karwacki, 2010; Otrębski, 2019).

For people experiencing various limitations due to disability, as aptly noted by Anna Brzezińska et al. (2008b, p. 129), "the very possibility of performing

${ }^{11}$ Office of the Government Plenipotentiary for People with Disabilities, Labour Market. Retrieved 30 August 2020 from: http://niepelnbezpieczni.gov.pl/index.php?c=page\&id=80\&print=1. 
work is, not only in their opinion, a specific 'proof' that they are the same as other people their age and have similar needs and the same rights that they do not fall outside the boundaries of society, which reduces the risk of their marginalization in society due to disability." However, such beliefs of these people, especially those with moderate and severe disabilities, may sometimes result in them undertaking work below formal qualifications, actual resources, plans and aspirations. The very possibility of doing it is highly appreciated by them, as it gives them a chance to experience contacts with others and failures similar to those of their able-bodied collaborators (Brzezińska et al., 2008a; 2008b). Therefore, it is worth bearing in mind, as in the conclusion of the research and analyses carried out by Brzezińska et al. (2008b), that in the projects of professional activation of people with disabilities, taking up and maintaining a job is not only another type of activity in adulthood, but above all a developmental task important in this period. Performing work requires coping with difficult situations, it also demands constant adaptation to changing conditions, thus stimulating development. The post-research indications of the author presenting the negative effects of excessive support for people with disabilities by the family and the institutions established for this should still be considered very topical. It can be a significant risk factor, as it results in the stagnation of the development process of these people - it can take away the sense of subjectivity and objectify, perpetuate helplessness, shape a demanding attitude towards loved ones, in the school and local environment, as well as in the work environment. Thus, effective help which leads to solving problems is primarily aimed at using own resources of people with disabilities and the resources of their immediate environment. It is then a pro-development, long-term and futureoriented aid. The priority is therefore own activity of people with disabilities supported in necessary and indispensable situations, always adequately to the needs and possibilities. Such highly personalized support also makes these people its contributors, and not just its recipients: dependent on others (Brzezińska et al., 2008b; Schalock et al., 2010). At the same time, the scope of professional and social competences of people with disabilities, necessary to function on the open labour market, as well as their active attitude to the current life situation should be developed through a diverse, accessible and high-quality offer of training, workshops and courses as part of lifelong learning. The inability to take advantage of such an offer may result in the lack of appropriate qualifications and increase the risk of unemployment, it also has an impact on the time of looking for a job or taking up employment below competences and not guaranteeing a salary giving a chance for independent existence (Miklewska, 2014). 
People with disabilities can fall into the trap of precariousness and related poverty, but they can also join the group of NEETs (not in employment, education or training) - people who are not in education, are not working and are not in training, and therefore often stay permanently outside the labor and education market, too often dependent on their family and socially marginalized. The NEET group is not homogeneous, but there are people, most often aged 15-29, with disabilities or ill $(6.8 \%$ - illness, disability - not seeking work due to illness or disability; includes those who need more social support because they cannot do paid work), who, without learning, do not develop, supplement or enrich their professional and social competences necessary to perform work and independent life. It is thus necessary to take actions aimed at effective elimination or even reduction of the risk of social exclusion of these people ${ }^{12}$. They are especially expected in the case of people with intellectual disabilities, as the risk of including them in the NEET group, compared to other groups, increases up to 40\% (Krause, 2016; Janiszewska-Nieścioruk \& Nieścioruk, 2019).

People with disabilities may also fall into the trap of precariousness, which is closely related to the aforementioned problem of unemployment. Unemployment is, in a way, a part of life in the precariat (Standing, 2014). Currently promoted as an advantage, flexibility of work is more and more often associated with the dissemination of its temporary forms, e.g. related to the implementation of a specific project, which reduce the employer's costs, but result in lower wages, limitation or liquidation of employee rights, and lack of continuity of employment. Such a situation leads to the use of temporary forms of work and at the same time increases the demand for them. It may also be associated with an increasing burden of duties, the aforementioned work below qualifications, the lack of opportunities for professional development, and periodic reduction of already low wages under the pretence of economic hardships. Uncertainty of the workplace and the fear of losing it facilitate the control and management of employees, forcing them to make concessions, and they often (themselves) commend employees in relations with the employer or intermediaries. And the progressive, especially in the current epidemic situation, development of remote work contributes to the fragmentation of employee groups and leads to their increasing isolation. The consequences of wage flexibility, which are low, more diversified and less predictable, may be equally severe, which in the event

12 NEETs Young people not in employment, education or training: Characteristics, costs and policy responses in Europe, European Foundation for the Improvement of Living and Working Conditions, Luxembourg 2012; Exploring the diversity of NEETs, European Foundation for the Improvement of Living and Working Conditions, Luxembourg 2016. 
of illness or disability deepens the economic uncertainty of many families, especially when they simultaneously have to struggle with the hostile complexities of the social benefits system (Sowa, 2010; Standing, 2014; Urbański, 2014).

In the context of the problems presented - the lack of certainty, stability and permanence in life and work, the impossibility of foreseeing the future, as well as the sense of threat caused by the ongoing epidemic, destabilizing the economic situation of many people in Poland - the life choices of people with disabilities may be limited to precarious possibilities. Such a situation becomes highly burdensome and therefore multiplies their disability. And although for a certain group of people a flexible way of working and lifestyle offers a sense of subjectivity, meeting their expectations and often high competences, for many people with disabilities it may mean a lack of material security, poverty and a constant threat of social exclusion. The problem is exacerbated by the fact that these people are constantly experiencing biologising their disability - excessive focusing on their physical, intellectual and psychological deficiencies instead of opportunities or resources (Standing, 2014; Twardowski, 2019; Niedbalski, 2019). Persistent qualification of people with disabilities to specific groups, which boils down to the gradation of their dysfunction instead of establishing the scope of the expected and necessary support, makes it difficult for them to establish social relations, develop self-determination and live independent lives.

\section{Final reflections}

Globalization and the associated clear economization of life intensify the polarization and social stratification of contemporary societies, more and more effectively "removing" their collective agency. These processes, as highly destructive, are also experienced in Poland, penetrating various spheres and areas of social and professional life as well as education to a different extent, revealing still unresolved problems of integration and inclusion of people with disabilities. Escalating inequalities among people caused by inadequate distribution of financial resources, limitations in the possibility of benefiting from civilization's goods and using a diversified and personalized offer of support too often pushes these people into the trap of precarity, unemployment and poverty. Pre-school education that does not meet their expectations and needs, and is often low-quality, which I also attempted to draw attention to, is unfortunately still poorly available, especially for students at an educational risk.

Moreover, being guided solely by reasons of the financial nature assumes minimizing the costs associated with social policy, i.e. with activities for the 
benefit of weaker (but not "redundant" people) who, without the help of others, will not be able to function independently. Officially, there is often talk of a better, more purposeful use of human resources, institutions, infrastructure, and de facto rather, it is about reducing the cost-consumption of such activities and forms of support (Żuraw, 2013).

Therefore, it should be borne in mind that the time of economic and social transformation, as well as new challenges and previously unknown problems related to the SARS-CoV-2 epidemic makes it necessary to adapt to new living conditions, which creative and personality-strong individuals will be able to cope with faster, and those with disabilities, coming from families with a low socioeconomic status, often remaining outside the labour market or threatened with precariousness and poverty, will not be able to deal with them without properly distributed support. Support that is not addictive, but activates these people in its process. Therefore, the indicated issues, as highly current and constituting the social and educational context of poverty of people with disabilities, require, in my opinion, depoliticizing, deinstitutionalising and de-hierarchizing the existing strategies and activities in this area in order to seek effective solutions, primarily at the community or local level. It seems that by using the forces inherent in the immediate environment of life, education and work of people with disabilities, assuming the cooperation of all entities involved to a varying degree in the process of their support and rehabilitation, it will be possible to create the conditions desired for the development of the key competences of these people. These competences, being a combination of knowledge, skills and attitudes, are currently necessary for them to fulfil themselves, co-decide about themselves and others, active citizenship, social integration and inclusion, as well as to exist and remain in the open labour market. Eliminating or even reducing the extent of poverty, often resulting in the marginalization and social exclusion of people with disabilities, should be perceived in terms of civic responsibility and democratization of the life of Polish society.

\section{References}

Becker-Pestka, D., Kubiński, G., \& Łojko, M. (2017). Różne obszary wykluczenia społecznego w Polsce: wybrane zagadnienia [Various Areas of Social Exclusion in Poland: Selected Issues]. Wrocław: Exante Wydawnictwo Naukowe.

Boryczko, M., Frysztacki, K., Kotlarska-Michalska, A., \& Mendel, M. (2016). Solidarnie przeciw biedzie [United Against Poverty]. Gdańsk: Europejskie Centrum Solidarności. 
Bourdieu, P., \& Passeron, J.K. (2006). Reprodukcja. Elementy teorii systemu nauczania [Reproduction. Elements of the Theory of the Teaching System]. Warszawa: Wydawnictwo Naukowe PWN.

Brzezińska, A.I., Kaczan, R., Piotrowski, K., Rycielski, P., Sijko, K., \& Wiszejko-Wierzbicka, D. (2008a). Uwarunkowania aktywności zawodowej osób z ograniczeniami sprawności: czynniki społeczno-demograficzne [Determinants of Economic Activity of People with Disabilities: Socio-Demographic Factors]. Nauka, 1, 129-150.

Brzezińska, A.N., Kaczan, R., Piotrowski, K., \& Rycielski, P. (2008b). Uwarunkowania aktywności zawodowej osób z ograniczeniami sprawności: kapitał osobisty i społeczny [Determinants of Economic Activity of People with Disabilities: Personal and Social Capital]. Nauka, 2, 129-156.

Cimek, G. (2017). Podstawowe problemy geopolityki i globalizacji [Basic Problems of Geopolitics and Globalization]. Gdańsk: Wydawnictwo Athenae Gedanenses.

Convention on the Rights of Persons with Disabilities (2006). Retrieved 15 June 2021 from: https://www.ohchr.org/EN/HRBodies/CRPD/Pages/ConventionRightsPersonsWithDisabilities.aspx.

Dolata, R. (2008). Szkoła - segregacje - nierówności [School - Segregation - Inequality]. Warszawa: Wydawnictwo Uniwersytetu Warszawskiego.

Domański, Z. (2016). Prekariat a bezpieczeństwo społeczne [The Precariousness vs. Social Security]. Journal of Modern Science, 3(30), 335-355.

The Draft Act on Equal Opportunities for People with Disabilities (2018). Retrieved 22 December 2020 from: http://www.niepelnosprawni.pl/files/www.niepelnosprawni.pl/public/formularze/ustawa_ostateczna.pdf.

Gasz, M. (2018). Rola programu Rodzina 500+ w procesie redukcji zagrożenia ubóstwem i wykluczeniem społecznym w Polsce [The Role of the Family 500+ Program in the Process of Reducing the Risk of Poverty and Social Exclusion in Poland]. Prace Naukowe Uniwersytetu Ekonomicznego we Wrocławiu [Scientific Papers of Wrocław University of Economy], 528, 88-101.

Gmerek, T. (2011). Edukacja i nierówności społeczne [Education and Social Inequalities]. Kraków: Oficyna Wydawnicza Impuls.

Goffman, E. (2005). Piętno. Rozważania o zranionej tożsamości [Stigma. Reflections on Wounded Identity]. Gdańsk: Gdańskie Wydawnictwo Psychologiczne.

Golinowska, S. (2008). Ocalić od wykluczenia społecznego [Rescue from Social Exclusion]. Dialog. Pismo Dialogu Społecznego, 1(18), 18-23.

Golinowska, S. (2010). Podatność młodzieży na ubóstwo i wykluczenie społeczne [Susceptibility of Youth to Poverty and Social Exclusion]. Kultura i Społeczeństwo, 3, 31-60. 
Horton, P.B., \& Leslie, G.R. (1970). Studies in the Sociology of Social Problems. New York: Appleton-Century-Crofts, New York.

Janiszewska-Nieścioruk, Z. (2012). Aktualne preferencje edukacyjne uczniów o specjalnych potrzebach i ich konsekwencje [Current Educational Preferences of Students with Special Needs and Their Consequences]. In: A. Krause, J. Belzyt, \& S. Sadowska (Eds.), Szkoła dla osób z niepetnosprawnością: wzory - codzienność - wyzwania [School for People with Disabilities: Patterns - Everyday Life - Challenges] (pp. 45-56). Gdańsk: Wydawnictwo Uniwersytetu Gdańskiego.

Janiszewska-Nieścioruk, Z., \& Nieścioruk, J. (2019). The Problematic Nature of the Social Inclusion of People with Intellectual Disability. Pedagogical Contexts, 2(13), 29-47, doi: 10.19265/KP.2019.21329.

Jarosz, M., \& Kozak, M.W. (2015). Eksplozja nierówności? [An Explosion of Inequality?]. Warszawa: Oficyna Naukowa.

Karwacki, A. (2006). Btędne koło. Reprodukcja kultury podklasy społecznej [Vicious Circle. Culture Reproduction of a Social Subclass]. Toruń: Wydawnictwo Naukowe Uniwersytetu Mikołaja Kopernika.

Kaźmierczak-Kałużna, I. (2012). Dwa oblicza biedy. Subiektywne i obiektywne aspekty sytuacji życiowej ubogich [The Two Faces of Poverty. Subjective and Objective Aspects of the Life Situation of the Poor]. Zielona Góra: Oficyna Wydawnicza Uniwersytetu Zielonogórskiego.

Kaźmierczak-Kałużna, I. (2016). Ja bym chciała, żeby moje dzieci mieli szczęśliwe dzieciństwo, nie tak, jak ja... Dzieciństwo własne a dzieciństwo własnych dzieci w narracjach wielodzietnych ubogich kobiet [I Wish My Children Had a Happy Childhood, not Like Me... Own Childhood vs. Childhood of One's Own Children in the Narratives of Poor Women with Many Children]. Opuscula Sociologica, 4(18), 63-79.

Kaźmierczak-Kałużna, I. (2019a). Kiedyś zaplanowałam może jeszcze pouczyć się trochę... Aspiracje edukacyjne a ich realizacja w narracjach wielodzietnych ubogich kobiet [Once I Planned to Learn a Little More... Educational Aspirations and Their Implementation in the Narratives of Poor Women with Many Children]. Dyskursy Młodych Andragogów, 20, 77-91.

Kaźmierczak-Kałużna, I. (2019b). W orbicie „500+”. Funkcjonowanie ubogich rodzin wielodzietnych w warunkach zmiany polityki rodzinnej w Polsce [Within the "500+" Orbit. The Functioning of Poor Families with Many Children in the Conditions of Changing Family Policy in Poland]. Kultura i Społeczeństwo, 63(4), 125-149, doi: doi. org/10.35757/KiS.2019.63.4.7.

Kosakowski, C. (2009). Węzłowe problemy pedagogiki specjalnej [Key Problems of Special Education]. Toruń: Wydawnictwo Akapit. 
Kotowska, I.E. (2007). Uwagi o polityce rodzinnej w Polsce w kontekście wzrostu dzietności zatrudnienia kobiet [Notes on Family Policy in Poland in View of the Increase in the Fertility Rate of Employment of Women]. Polityka Spoteczna, 8, 13-19.

Krause, E. (2016). Zjawisko NEET, czyli o młodzieży trzy razy nic [The NEET Phenomenon, or Three Times Nothing about Young People]. Polskie Towarzystwo Profesjologiczne. Problemy Profesjologii, 2, 67-81.

Krause, A., Żyta, A., \& Nosarzewska, S. (2010), Normalizacja środowiska społecznego osób $z$ niepetnosprawnościa intelektualna [Normalization of the Social Environment of People with Intellectual Disabilities]. Toruń: Wydawnictwo Akapit.

Krawczyk, M. (2019). Świadczenie 500+ jako element polityki prorodzinnej i demograficznej państwa [500+ Benefit as an Element of the Pro-Family and Demographic Policy of the State]. Zeszyty Naukowe Uniwersytetu Przyrodniczo-Humanistycznego w Siedlcach, 120, Series: Administracja i Zarządzanie (47), 57-62.

Kwieciński, Z. (2002). Wykluczanie [Exclusion]. Toruń: Wydawnictwo Uniwersytetu Mikołaja Kopernika.

Melosik, Z. (2015). Edukacja i stratyfikacja społeczna [Education and Social Stratification]. In: K. Błasińska, S. Pasikowski, G. Piekarski, \& J. Ratkowska-Pasikowska (Eds.), Nierówności społeczne. W trosce o otwarcia horyzontów edukacji [Social Inequalities. For the Sake of Opening up the Horizons of Education] (pp. 15-33). Gdańsk: Fundacja Instytut Równowagi Społeczno-Ekonomicznej.

Mendryk, I., Kawczyńska-Butrym, Z., Oleszko-Kurzyna, B., \& Galbarczyk, T. (2020). Gospodarstwa domowe z 500+ w procesie rozwoju kapitalu ludzkiego. Wybrane problemy ekonomiczne i socjologiczne [Households with 500+ in the Process of Human Capital Development. Selected Economic and Sociological Problems]. Warszawa: C.H. Beck.

Miklewska, A. (2014). Kształcenie ustawiczne jako szansa na podjęcie zatrudnienia przez osoby niepełnosprawne [Lifelong Learning as an Employment Opportunity by Disabled People]. Podstawy, 7, 317-344.

Mikołajczyk-Lerman, G. (2013). Między wykluczeniem a integracją. Realizacja praw dziecka niepetnosprawnego i jego rodziny [Between Exclusion and Integration. Implementation of the Rights of a Disabled Child and Their Family]. Łódź: Wydawnictwo Uniwersytetu Łódzkiego.

Murawska, B. (2004). Segregacje na progu szkoty podstawowej [Segregation at the Threshold of Primary School]. Warszawa: Instytut Spraw Publicznych.

Murawska, B. (2006). Dzieci z grup edukacyjnego ryzyka [Children from Educational Risk Groups]. In: T. Szlendak (Ed.), Małe dziecko w Polsce - raport o sytuacji edukacji elementarnej [A Small Child in Poland - A Report on the Situation of Elementary Education] (pp. 103-119). Warszawa: Fundacja Rozwoju Dzieci im. J.A. Komeńskiego. 
Niedbalski, J. (2019). Niepetnosprawność i osoby z niepetnosprawnościa. Od pasywności $i$ wykluczenia do aktywności życiowej $i$ integracji społecznej [Disability and People with Disabilities. From Passivity and Exclusion to Life Activity and Social Integration]. Łódź: Wydawnictwo Naukowe UŁ.

Nowak, A. (2012a). Wstęp [Introduction]. Chowanna, 1(38), 11-14.

Nowak, A. (2012b). Pojęcie, istota, przyczyny, mechanizmy marginalizacji i wykluczenia społecznego [The Concept, Essence, Causes, Mechanisms of Marginalization and Social Exclusion]. Chowanna, 1(38), 17-32.

Nowak, A. (2012c). Zagrożenie wykluczeniem spolecznym kobiet niepetnosprawnych [Threat of Social Exclusion of Disabled Women]. Katowice: Wydawnictwo Uniwersytetu Śląskiego.

Otrębski, W. (2019). Start w dorosłość - uwarunkowania, wyznaczniki oraz proces przejścia z edukacji do rynku pracy uczniów ze specjalnymi potrzebami edukacyjnymi [Off into Adulthood - Conditions, Determinants and the Process of Transition from Education to the Labour Market of Students with Special Educational Needs]. In: G. Szumski, \& I. Chrzanowska (Eds.), Edukacja wtaczajaca w przedszkolu i szkole [Inclusive Education in Kindergarten and School] (pp. 236-247). Warszawa: Wydawnictwo FRSE.

Pałęcka, A., \& Płucienniczak, P.P. (2017). Niepewne zatrudnienie, lęk i działania zbiorowe. Trzy wymiary prekarności [Insecure Employment, Anxiety and Collective Action. The Three Dimensions of Precariousness]. Kultura i Społeczeństwo, 4, 61-68.

Poniat, R. (2013). Ludzie luźni w społeczeństwie Rzeczypospolitej szlacheckiej w kontekście badań nad cyklem życia [Loose People within the Society of the Noble Republic in the Context of Research on the Life Cycle]. Roczniki Dziejów Spolecznych i Gospodarczych, 73, 51-77.

Radziewicz-Winnicki, A., \& Roter, A. (2004). Ryzyko transformacyjne nowego ładu społeczno-edukacyjnego [Transformational Risk of the New Social and Educational Order]. Katowice: Śląska Wyższa Szkoła Zarządzania im. gen. Jerzego Ziętka.

Roter, A., (2005). Proces socjalizacji dzieci w warunkach ubóstwa społecznego [The Socialization Process of Children in Conditions of Social Poverty]. Katowice: Wydawnictwo Uniwersytetu Śląskiego.

Schalock, R.L., Luckasson, R., \& Tassé, M.J. (2010). Intellectual Disability. Definition, Classification, and Systems of Supports, $11^{\text {th }} \mathrm{ed}$. Washington: AAIDD.

Senge, P.M. (2012). Piata dyscyplina. Teoria i praktyka organizacji uczacych się [The Fifth Discipline. The Theory and Practice of Learning Organizations]. Warszawa: Wolters Kluwer. 
Sęk, H., \& Cieślak, R. (2011). Wsparcie społeczne - sposoby definiowania, rodzaje i źródła wsparcia, wybrane koncepcje teoretyczne [Social Support - Ways of Defining, Types and Sources of Support, Selected Theoretical Concepts]. In: H. Sęk, \& R. Cieślak (Eds.), Wsparcie spoleczne stres i zdrowie [Social Support Stress and Health] (pp.11-28). Warszawa: Wydawnictwo Naukowe PWN.

Smolińska-Theis, B. (2008). Lepiej urodzeni - lepiej kształceni [Better Born - Better Educated]. In: M. Dudzikowa, \& M. Czerepaniak-Walczak (Eds.), Wychowanie. Pojęciaprocesy - konteksty. Interdyscyplinarne ujęcie, t. 4 [Upbringing. Concepts - Processes - Contexts. An Interdisciplinary Approach, Vol. 4] (pp. 423-441). Gdańsk: Gdańskie Wydawnictwo Psychologiczne.

Smolińska-Theiss, B. (2016). Dzieci w Polsce - najbiedniejsza grupa społeczna [Children in Poland - The Poorest Social Group]. Pedagogika Społeczna, 4(62), 77-95.

Sowa, J. (2010). Prekariat - proletariat epoki globalizacji [Precariat - The Proletariat of the Globalization Era]. In: J. Sokołowska (Ed.), Robotnicy opuszczają miejsca pracy [Workers are Leaving Their Jobs] (pp. 100-132). Łódź: Muzeum Sztuki w Łodzi.

Standing, G. (2014). Prekariat. Nowa niebezpieczna klasa [Precariat. The New Dangerous Class]. Trans. by K. Czarnecki, P. Kaczmarski, \& M. Karolak. Warszawa: Wydawnictwo Naukowe PWN.

Szarfenberg, R. (2006). Marginalizacja i wykluczenie społeczne. Wykłady [Marginalization and Social Exclusion. Lectures]. Warszawa: Uniwersytet Warszawski.

Szarfenberg, R. (2016). Prekarność, prekaryjność, prekariat - krótkie wprowadzenie [Precarity, Precariousness, Precariat - Brief Introduction] (version 3.5, 03.01.16). Retrieved 22 December 2020 from: http://rszarf.ips.uw.edu.pl/pdf/prekariat3.5.pdf.

Szkudlarek, T. (2007). Edukacja i konstruowanie społecznych nierówności [Education and Construction of Social Inequalities]. In: J. Klebaniuk (Ed.), Fenomen nierówności spotecznych [The Phenomenon of Social Inequalities] (pp. 31-52). Warszawa: ENETEIA Wydawnictwo Psychologii i Kultury.

Śliwerski, B. (2008). Oświatowy remanent, czyli o ideologicznym majsterkowaniu polityków oświatowych w latach 1989-2006 [Educational Inventory, i.e. on the Ideological Tinkering of Educational Politicians in the Years 1989-2006]. In: M. Dudzikowa, \& M. Czerepaniak-Walczak (Eds.), Wychowanie. Pojęcia - procesy - konteksty. Interdyscyplinarne ujęcie [Upbringing. Concepts-Processes-Contexts. An Interdisciplinary Approach] (pp. 95-140). Gdańsk: Gdańskie Wydawnictwo Psychologiczne.

Śliwerski, B. (2015). Edukacja (w) polityce. Polityka (w) edukacji. Inspiracje do badań polityki oświatowej [Education (in) Politics. Politics (in) Education]. Inspirations for Educational Policy Research]. Kraków: Oficyna Wydawnicza Impuls. 
Tarkowska, E. (2006). Ubóstwo dzieci i młodzieży a edukacja [Poverty of Children and Youth and Education]. In: S. Golinowska, \& M. Boni (Eds.), Nowe dylematy polityki społecznej [The New Dilemmas of Social Policy] (pp. 226-243). Warszawa: CASE Centrum Analiz Społeczno-Ekonomicznych.

Tarkowska, E. (2008). „Nie masz kasy, jesteś nikim”. O pogłębianiu nierówności przez szkołę ["You Have no Money, You Are Nobody." On the Deepening of Inequalities by Schools]. In: M. Dudzikowa, \& M. Czerepaniak-Walczak (Eds.), Wychowanie. Pojęcia - procesy - konteksty. Interdyscyplinarne ujęcie [Upbringing. Concepts-Processes-Contexts. An Interdisciplinary Approach]. Gdańsk: Gdańskie Wydawnictwo Psychologiczne.

Tarkowska, E. (2013). Bieda, ubóstwo i inne kategorie dyskursu akademickiego w Polsce [Poverty and Other Categories of Academic Discourse in Poland]. In: E. Tarkowska (Ed.), Dyskursy ubóstwa i wykluczenia [Discourses of Poverty and Exclusion] (pp. 49-90). Warszawa: Wydawnictwo IFiS PAN.

Tarkowska, E., Górniak, K., \& Kalbarczyk, A. (2006). System edukacji, ubóstwo, wykluczenie społeczne [The Education System, Poverty, Social Exclusion]. Polityka Społeczna, 11-12, 29-33.

Twardowski, A. (2019). Disability Studies jako nowa, interdyscyplinarna dziedzina badań nad niepełnosprawnością [Disability Studies as a New, Interdisciplinary Field of Research on Disability]. In: Z. Janiszewska-Nieścioruk, A. Mróz, \& U. Gembara (Eds.), (Nie)nowe problemy rozwoju, edukacji i rehabilitacji osób z niepetnosprawnościa intelektualna [(Not) New Problems in the Development, Education and Rehabilitation of People with Intellectual Disabilities] (pp. 59-69). Zielona Góra: Oficyna Wydawnicza Uniwersytetu Zielonogórskiego.

Urbański, J. (2014). Prekariat i nowa walka klas. Przeobrażenia współczesnej klasy pracowniczej i jej form walki [Precariat and the New Class Struggle. Transformations of the Contemporary Working Class and its Forms of Struggle]. Warszawa: Instytut Wydawniczy Książka i Prasa.

Wolny, J. (2020). Obywatel z niepelnosprawnościa intelektualna. Obszary działań i propozycje rozwiąań w projekcie „Aurora znaczy jutrzenka” [A Citizen with Intellectual Disability. Areas of Activity and Proposed Solutions in the "Aurora Means Dawn" Project]. Toruń: Wydawnictwo Adam Marszałek.

Żółkowska, T. (2004). Wyrównywanie szans społecznych osób z niepetnosprawnościa intelektualna: uwarunkowania i obszary [Equalizing Social Opportunities for People with Intellectual Disabilities: Conditions and Areas]. Szczecin: Oficyna InPlus. 
Żółkowska, T. (2011). Normalizacja - niedokończona teoria praktyki [Normalization - The Unfinished Theory of Practice]. Niepetnosprawność. Dyskursy Pedagogiki Specjalnej, 5, 85-93.

Żuraw, H. (2013). Between Theory and Practice of Living with Disabilities - Myths and Areas of Hypocrisy in Studies on People with Disabilities. Niepetnosprawność. Dyskursy Pedagogiki, 10, 18-41. 